\title{
Inorganic nitrogen utilization by assemblages of marine bacteria in seawater culture*
}

\author{
S. G. Horrigan ${ }^{1}, \AA$. Hagström ${ }^{2}$, I. Koike ${ }^{3}$, F. Azam ${ }^{4}$ \\ ${ }^{1}$ Marine Sciences Research Center, SUNY-Stony Brook, Stony Brook, New York 11794, USA \\ ${ }^{2}$ Department of Microbiology, University of Umeå, S-901 87 Umeå, Sweden \\ ${ }^{3}$ Ocean Research Institute, University of Tokyo, Nakano, Tokyo 164, Japan \\ ${ }^{4}$ Scripps Institution of Oceanography, University of California, San Diego, La Jolla, California 92093, USA
}

\begin{abstract}
Stimulation of heterotrophic bacterial growth by inorganic nitrogen (nitrate and ammonium) was observed in natural assemblages of marine bacteria grown in continuous culture with unsupplemented sea water as primary medium. In the presence of nitrogenous supplements, bacterial numbers increased approximately 3 -fold. These results indicate that re-evaluation of the role of heterotrophic bacterioplankton in the pelagic nitrogen cycle may be necessary.
\end{abstract}

\section{INTRODUCTION}

In the classical view of the pelagic marine nitrogen cycle, heterotrophic bacteria have been portrayed as net mineralizers, producing ammonium from dissolved organic nitrogen (DON). Assimilation of dissolved inorganic nitrogen (DIN) as regenerated ammonium or upwelled nitrate is thought to be due mainly to phytoplankton. Recently, several lines of evidence have suggested that heterotrophic bacteria might be significant consumers of the inorganic $N$, in competition with phytoplankton (which are generally $\mathrm{N}$-limited in the marine pelagial). Indirect evidence comes from an inability to balance a nitrogen budget without invoking DIN uptake by bacteria (Laws et al. 1985). Additional evidence comes from DIN uptake studies using specific inhibitors for prokaryotes and eukaryotes, respectively (Wheeler \& Kirchman 1986) and ${ }^{13} \mathrm{NH}_{4}^{+}$followed by size-fractionation (Fuhrman et al. 1988). Further, laboratory studies have demonstrated growth of marine bacteria using nitrate as a nitrogen source (Brown et al. 1972), and field and mesocosm studies suggest that bacteria may limit autotrophic production by competing for nitrate (Parker et al. 1975, Parsons et al. 1981).

We studied DIN uptake by natural assemblages of bacteria grown in seawater cultures. We also asked whether DIN additions, made in the second stage of a

\footnotetext{
- Contribution No. 617 of the Marine Sciences Research Center, SUNY, Stony Brook, USA
}

2-stage continuous culture, would stimulate bacterial growth. The use of the seawater culture system allowed us to examine DIN uptake by bacteria in the absence of other organisms; yet we could study presumably complex bacterial assemblages growing in unenriched seawater (except when DIN was added) at cell densities and growth rates comparable to those in natural bacterial assemblages.

\section{MATERIALS AND METHODS}

Continuous culture system. The experimental apparatus consisted of a 2 -stage continuous culture (Fig. 1). The first stage was a 'seawater culture', using filtered (Whatman GF/C, followed by $0.22 \mu \mathrm{m}$ Millipore), autoclaved seawater collected from Scripps Pier as the medium (Reservoir I in Fig. 1) and $1 \mu \mathrm{m}$ filtered (Nuclepore) seawater as the inoculum (Hagström et al. 1984). The growth vessel for the first stage was a $250 \mathrm{ml}$ side-arm flask (Chemostat I in Fig. 1). A series of medium supplements, contained in Reservoir II (Fig. 1), were added to the second stage of the continuous culture (Chemostat II in Fig. 1). The growth vessel for the second stage was a covered graduated cylinder, and held a volume of about $310 \mathrm{ml}$. The graduated cylinder served as a mixing vessel for the overflow from the first stage and the medium added from the supplemental reservoir, which were mixed in the ratio of 4 parts overflow from Chemostat I to 1 part medium from 


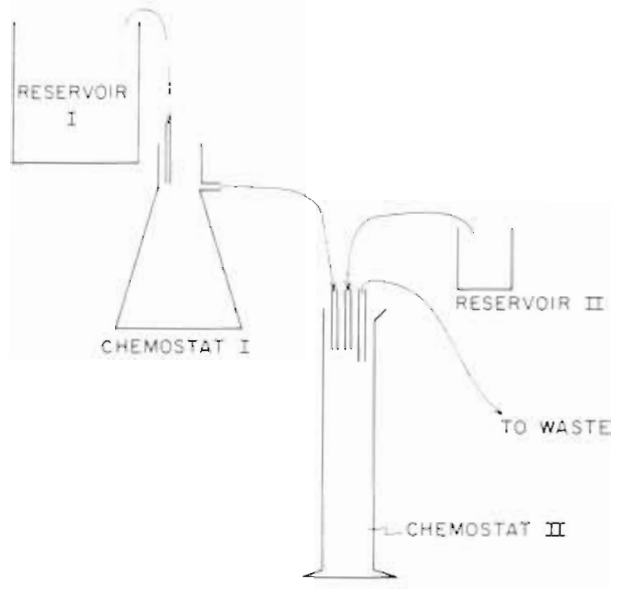

Fig. 1. Experimental set-up for laboratory studies, showing the 2 nutrient reservoirs and the 2 stages

the supplemental reservoir. The volume of the second stage was proportionally larger to accommodate the supplemental medium. The supplements to the second stage of the continuous culture were filtered, autoclaved solutions in seawater of ammonium, phosphate, the outflow from a nitrogen-limited phytoplankton chemostat, presumed to be a source of dissolved organic matter (DOM) (courtesy of D. G. Redalje), filtered seawater as a control, and nitrate. The supplements were added sequentially over time. The dilution rate was maintained at $0.055 \mathrm{~h}^{-1}$, for a doubling time of $18 \mathrm{~h}$. The first stage was allowed to reach steady state, as determined by constant cell numbers. Supplemental additions to the second stage were then begun. The experimental apparatus was maintained in the dark, at a temperature of ca $20^{\circ} \mathrm{C}$.

Analyses. Bacterial cell numbers in each stage were determined periodically by epifluorescence microscopy (Hobbie et al. 1977, Hagström et al. 1979). Nutrients (ammonium, nitrate, phosphate) were determined by colorimetric methods (Strickland \& Parsons 1972).

\section{RESULTS}

\section{Bacterial abundance}

Cell numbers in the first stage remained constant over the $44 \mathrm{~d}$ of the experiment $10.83 \pm 0.18 \times 10^{6}$ cells $\mathrm{ml}^{-1}, n=21$ ). No changes were seen over the course of the experiment (Pearson's product moment correlation. $=-0.07$ ) (Fig. 2) Cell numbers in the second stage varied depending on the supplement supplied in the supplemental reservoir. When autoclaved filtered seawater, the same medium as supplied to the first stage, was the supplement, there was no significant difference in cell concentrations between the 2 stages (Stu-

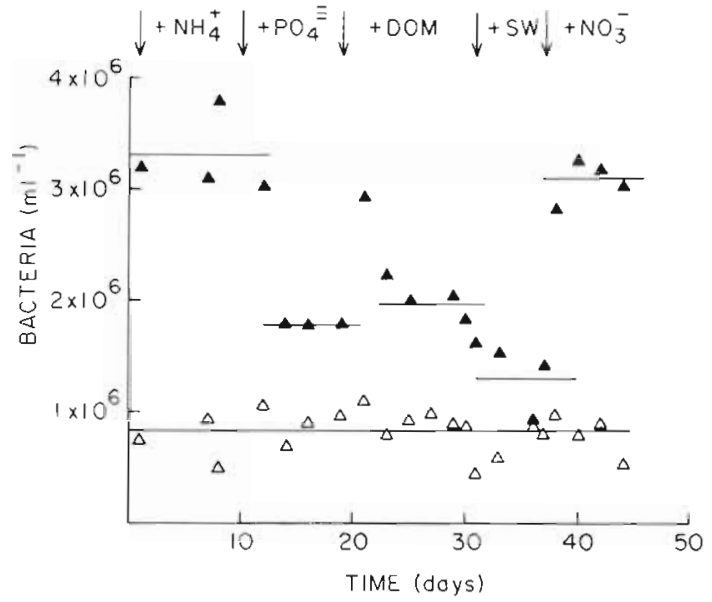

Fig. 2. Cell numbers in the first stage $(\Delta)$ and second (supplemented) stage (A) of the 2-stage continuous culture. Arrows: supplemental reservoir was changed

dent's t-test, $p>0.05$ ) (Fig. 2). Cell numbers in the second stage were significantly greater than in the first stage for all other supplements, nitrogen as ammonium or nitrate, phosphorus as phosphate, and DOM as the overflow from a nitrogen-limited phytoplankton chemostat. When ammonium or nitrate was the supplement, cell numbers in the second stage were about $3 \times$ higher than in the first stage. Cell numbers were approximately twice those in the first stage when phosphate or DOM was the supplement.

\section{Nutrient removal}

Concentrations of nitrogenous nutrients (sum of ammonium, nitrite, and nitrate) and soluble reactive phosphorus in the inflow and outflow for each treatment are summarized in Table 1. Some of the variability in nutrient concentrations is due to the temporal variability in seawater collected from Scripps Pier; the reservoirs were replenished with freshly-collected seawater several times during the course of the experiment. In addition, carryover of the previous enrichment contributed to the variability in nutrient concentrations. This is especially noticeable in the phosphate concentrations (Table 1). The outflow represents steady-state concentrations in the continuous culture, so that the amount of nutrients utilized can be calculated by difference. The budget for nitrogen species cannot be complete, because the dissolved organic nitrogen pools were not measured. Presumably, dissolved organic nitrogen compounds were particularly important in the 'DOM' supplement.

The inflow to the first stage contained $2.21 \mathrm{\mu mol}$ $\mathrm{N} \mathrm{I}^{-1}, 1.77 \mu \mathrm{mol} \mathrm{l}^{-1}$ as ammonium, and $0.44 \mathrm{~mol} \mathrm{l}^{-1}$ as 
Table 1. Bacterial numbers and concentrations of nutrients in chemostat reservors

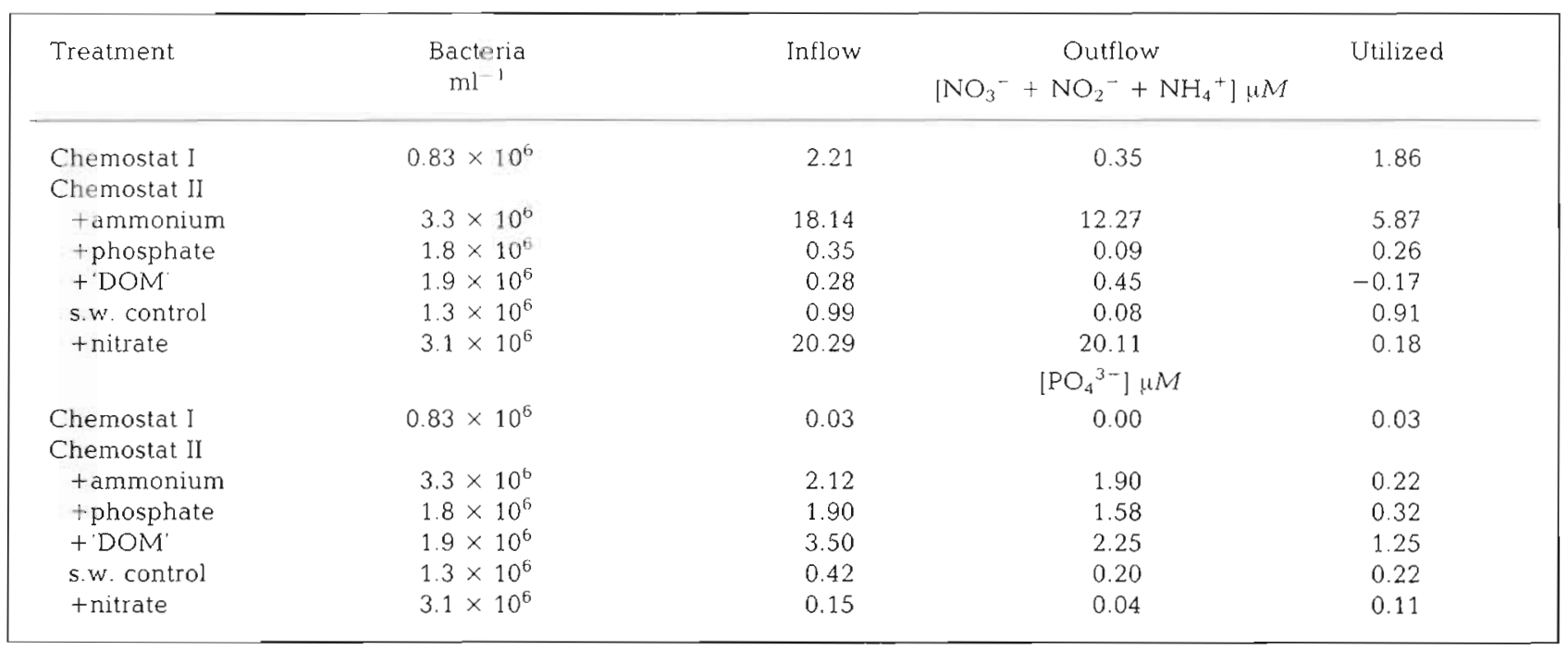

nitrate + nitrite. The DIN species in the outflow from the first stage were only nitrate + nitrite; the concentration of ammonium in the outflow was at the detection limit for the method $\left(<0.02 \mu \mathrm{mol}^{-1}\right)$.

\section{DISCUSSION}

Several recent studies have indicated that heterotrophic marine bacteria may compete with phytoplankton for nutrient assimilation (Bratback \& Thingstad 1985, Laws et al. 1985, Wheeler \& Kirchman 1986, Fuhrman et al. 1988). Our study confirms the uptake of inorganic nitrogen, not only ammonium but also nitrate, by a culture of mixed marine heterotrophic bacteria. Furthermore, we have demonstrated by the increase in bacterial concentrations in the supplemented continuous culture, that inorganic nitrogen can enhance the growth of heterotrophic bacteria in these seawater cultures

The experimental conditions in the continuous culture are different from natural ones, however. In the experimental set-up, the supply of fresh nutrients is the input from a reservoir, rather than from in situ regenerative processes. The dissolved organic and inorganic matter could be qualitatively and quantitatively different from that in natural seawater. In addition, the major source to the second stage of the continuous culture is the outflow from the first stage. Thus the second stage is different from the first not only in the addition from the supplemental reservoir, but also in the quality and quantity of the dissolved material in the inflow. In other words, in the inflow to the second stage, some of the dissolved material that was present in Reservoir I has turned into bacterial biomass.
Nevertheless, it is interesting to note that the supplemental addition of dissolved organic matter in the form of the overflow from a nitrogen-limited phytoplankton chemostat did not stimulate an increase in bacterial numbers comparable to that caused by the addition of either of the 2 inorganic nitrogen compounds, ammonium or nitrate.

Our loss term is the outflow from the continuous culture. In the real ocean, where loss is probably due to grazing, there is a feedback from the grazing term, in that grazing is a source of fresh nutrients (Goldman et al. 1985, Sherr et al. 1986). No such feedback is present in the chemostat system. Nevertheless, the observed increase in numbers of bacteria in the presence of added inorganic nitrogen indicates that supplies of inorganic nutrients to the bacterial population may be important in determining the bacterial standing stock.

The impact of heterotrophic bacteria on the flows of carbon and energy in pelagic ecosystems has been demonstrated (Hagström et al. 1979, Fuhrman \& Azam 1980,1982 ), and their role has now been incorporated into classical paradigms of carbon and energy cycling (Williams 1981). This study, along with other recent studies, indicates that the role of heterotrophic bacterioplankton in the pelagic nitrogen cycle may need re-evaluation as well. For example, we can use the nitrate utilization rates in this study to estimate the potential impact of the bacterial population on measurements of new production. The continuous culture system contains bacterial numbers and nitrogen concentrations which are ecologically relevant to the Southern California Bight system (Fuhrman et al. 1980). By extrapolation from the measured nitrate utilization rates in the first stage of the continuous culture, we find that bacterial uptake can account for $\sim 50 \mathrm{mg} \mathrm{N}$ 
$\mathrm{m}^{-2} \mathrm{~d}^{-1}$. When nitrate is used as the supplement in the second stage, perhaps mimicking pulses of nitrate to the mixed layer, $-200 \mathrm{mg} \mathrm{N} \mathrm{m} \mathrm{N}^{-2} \mathrm{~d}^{-1}$ would be utilized by heterotrophic bacteria. These extrapolated rates could account for the entire measured nitrate assimilation in Southern California Bight waters during some seasons (Eppley et al. 1979). If a large percentage of nitrate uptake in the upper mixed layer should be channelled via bacteria, there are both conceptual and practical implications. Practically, the contribution of bacterial uptake to rates measured by incubation experiments with added ${ }^{15} \mathrm{~N}$-substrates must be assessed. Conceptually, our understanding of the pathways and mechanisms of nitrogen flow must be reevaluated.

Acknowledgements. We thank R. W. Eppley for the use of laboratory facilities, and C. Lee, Karl Banse and J. A. Fuhrman for comments on the manuscript. This work was supported by US Department of Energy contract DE-AT03-82-ER60031 and National Science Foundation grant OCE79-26458 and OCE87-16994. Further support was provided by the Swedish Natural Science Research Council grant B-PD 4452-106, and NSF grant OCE-8417595.

\section{LITERATURE CITED}

Bratbak, G., Thingstad, T F. (1985). Phytoplankton-bacteria interactions: an apparent paradox? Analysis of a model system with both competition and commensalism. Mar. Ecol. Prog. Ser. 25: 23-30

Brown, C. M., MacDonald-Brown, D. S., Stanley, S. O. (1972) Inorganic nitrogen metabolism in marine bacteria: nitrogen assimilation in some marine pseudomonads. J. mar biol. Ass. U.K. 52: 793-804

Eppley, R. W., Renger, E. H., Harrison, W G. (1979). Nitrate and phytoplankton production in southern California coastal waters. Limnol. Oceanogr. 24: 483-494

Fuhrman, J. A., Ammerman, J. W., Azam, F. (1980). Bacterioplankton in the coastal euphotic zone: distribution, activity, and possible relationship with phytoplankton. Mar Biol. 60: 201-207

Fuhrman, J. A., Azam, F. (1980). Bacterioplankton secondary production estimates for coastal waters of British Columbia, Antarctica, and California. Appl. environ. Microbiol. 39: 1085-1095

Fuhrman, J. A., Azam, F. (1982). Thymidine incorporation as a measure of heterotrophic bacterioplankton production in marine surface waters: evaluation and field results. Mar Biol. 66: 109-120

Fuhrman, J. A., Horrigan, S. G., Capone, D. G. (1988). Use of ${ }^{13} \mathrm{~N}$ as tracer for bacterial and algal uptake from seawater. Mar. Ecol. Prog. Ser. 45: 271-278

Goldman, J. C., Caron, D. A.. Andersen, O. K., Dennett, M. R. (1985). Nutrient cycling in a microflagellate food chain: I. Nitrogen dynamics. Mar. Ecol. Prog. Ser. 24: 231-242

Hagström, A., Ammerman, J. W., Henrichs, S., Azam, F. (1984). Bacterioplankton growth in seawater. II. Organic matter utilization during steady-state growth in seawater cultures. Mar. Ecol. Prog. Ser. 18: 41-48

Hagström, §.. Larsson, U., Horstedt, P., Normark, S. (1979). Frequency of dividing cells, a new approach to the determination of bacterial growth rates in aquatic environments. Appl. environ. Microbiol. 37: 805-812

Hobbie, J. E., Daley, R. J., Jasper, S. (1977). Use of Nuclepore filters for counting bacteria by epifluorescence microscopy. Appl. environ. Microbiol. 33: 1225-1228

Laws, E. A., Harrison, W. G., DiTullio, G. R. (1985). A comparison of nitrogen assimilation rates based on ${ }^{15} \mathrm{~N}$ uptake and autotrophic protein synthesis. Deep Sea Res. 32: 85-95

Parker, R. R., Siebert, J., Brown, T. J. (1975). Inhibition of primary productivity through heterotrophic competition for nitrate in a stratified estuary. J. Fish. Res. Bd Can. 32: $72-77$

Parsons, T. R., Albright, L. J., Whitney, F., Wong, C. S., Williams, P. J. LeB. (1981). The effect of glucose on the productivity of seawater: an experimental approach using controlled aquatic ecosystems. Mar. environ. Res. 4: 229-242

Sherr, B. F., Sherr, E. B., Andrew, T. L., Fallon, R. D., Newell, S. Y (1986). Trophic interactions between heterotrophic Protozoa and bacterioplankton in estuarine water analyzed with selective metabolic inhibitors. Mar. Ecol. Prog. Ser. 32: 169-179

Strickland, J. D. H., Parsons, T. R. (1972). A practical handbook of seawater analysis. Bull. Fish. Res. Bd Can. 167

Wheeler, P. A., Kirchman, D. L. (1986). Utilization of inorganic and organic nitrogen by bacteria in marine systems. Limnol. Oceanogr. 31: 998-1009

Williams, P. J. LeB. (1981). Incorporation of microheterotrophic processes into the classical paradigm of the planktonic food web. Kieler Meeresforsch., Sonderh. 5: 1-28 